\title{
The Dynamics of Restraint in Côte d'Ivoire
}

\author{
Jeremy Allouche and Patrick Anderson Zadi Zadi*
}

\begin{abstract}
Research on conflict prevention has mainly focused on the causes of war and post-conflict reconstruction. Our knowledge on how civilians manage to contain violence in unstable and conflict environments is, however, very limited. This article aims to understand, in the context of the civil war in Côte d'lvoire, how and why 'islands of peace' emerge during outbreaks of violence. It identifies both the local and structural conditions and mechanisms (including formal and informal) that help to mitigate violence and encourage restraint in conflict-affected and unstable situations. Our research and analysis has focused on the western region, which is the epicentre of violence. Semi-structured interviews with Young Patriots members, the military, the business community, representatives of women's NGOs, traditional leaders and representatives of the religious community, along with interviews in Abidjan, provided the primary data for our analysis.
\end{abstract}

\section{Introduction}

Côte d'Ivoire used to be known in sub-Saharan Africa for its political stability, but the 1990s revealed social and economic fragilities which plunged the country into precarious unrest and instability. The coup of 1999 and the unsuccessful coup attempt of September 2002 were manifest illustrations of this socioeconomic and political fragility. Since then, Côte d'Ivoire has suffered from outbreaks of violence, especially in Abidjan and in the west of the country. For many specialists, the crisis is one of identity (Dembélé et al. 2002). However, according to our field analysis in the most affected areas, the question of land tenure is by far the most important issue. Indeed, the most affected area in Côte d'Ivoire is the western region of the country, the most important one for cocoa production. The region has attracted a number of migrants from neighbouring countries, especially from Burkina Faso but also Mali and Guinea, as well as internal migrants from the Baoulé region. The land tenure issue has become politicised and the question of Ivoirité (i.e. 'Ivorianness' - a radical ethno-nationalist understanding of Ivorian citizenship) has been instrumentalised to the needs of the most powerful in the region. As a result, local incidents can easily become regional conflicts and create national tensions.
The split of Côte d'Ivoire cannot be understood within the constructed borders imagined by the politicians or even those drawn as a result of the Linas-Marcoussis agreement. ${ }^{1}$ Those authors who follow such an analysis usually wrongly describe this split as between 'a governmental Christian and animist zone in the South versus a rebel Muslim zone in the North' (see the criticism by Bassett 2003). The west has been the epicentre of violence since the beginning of the civil war in 2002. The political crisis that resulted from the 2010 presidential elections escalated into a full-scale military conflict between forces loyal to Laurent Gbagbo, the president of Côte d'Ivoire since 2000, and supporters of the internationally recognised president-elect Alassane Ouattara, with again the west as the geostrategic centre of the military battlefield. The interesting paradox of the 2011 post-electoral crisis is that except for the massacres in Duékoué (see Table 1), violence has been more limited in urban centres (in terms of numbers of events and the scale in proportion to the size of the area). This is not the case in rural areas where cycles of revenge and retaliation have continued well after the postelectoral crisis. The objective of this article is to highlight a number of factors that could explain this dynamic of restraint in urban areas in the west, and to explain why there has not been 
direct violence against the civilian population in urban areas in the context of the post-electoral crisis. This research angle is interesting and original (if not provocative) in the sense that there are not many, if any, sociological and political analyses which have looked in detail at the dynamics of restraint during civil war.

This article is divided into four parts: the following section will review the relevant literature while sections 3 to 7 will focus respectively on the west as the epicentre of the conflict, a presentation of the cities visited for this research and an explanation of why violence was absent or restrained in a number of places. Section 8 concludes.

\section{Inverting the question}

How can we explain why physical violence during a civil war is limited to a specific geographical area? This has become a classic puzzle in recent studies on violence and civil war. Kalyvas (2006), for example, starts his book with the example of two very similar and contiguous Greek villages in the peninsula of the Peloponnese that faced two different trajectories: one resulted in a general massacre while the other prevented this type of violence. These micro-level theories on violence and civil war (see also Varshney 2002; Wood 2003) have clearly shifted the debate away from the habitually cited causes of group division (e.g. social or ethnic polarisation) that often fail to account for the actual dynamics of violence. In fact, these new theories have been very successful in explaining the causes of variation in violence and distinguishing them from a general theory of conflict and war. However, most academics, whether Varshney (2002) in terms of social cohesion or Kalyvas (2006) in terms of levels of territorial contestation, use the same variables to explain both the prevalence of violence and its absence. However, one could contend that the political dynamics of the avoidance of violence can be separated from those of violence.

Like many large-scale modern violent conflicts, the war in Côte d'Ivoire was a combination of conventional warfare between military insurgents and the army, and targeted violence by both insurgents and the army against noncombatants. This article will focus on the latter but wishes to invert the debate by examining spaces where this violence did not happen. Our general 'obsession' as human beings has been to try to understand rationally why 'other' human beings commit violence, thereby ignoring how individuals and groups have managed to escape from this violence during periods of armed conflict. In general, these third party actors have been seen as passive, as the storylines and analyses of most civil wars focus on the insurgents and the army. There have been a few stories and narratives of acts of resistance that were reported in Rwanda, for example, but these are just anecdotes that fail to illustrate the potential political strategies that are used by non-combatants to escape violence.

Recent work by Blattman and Miguel (2009: 1) argues that micro-level analysis and data are needed to better understand the roots of war and the behaviour of armed groups. The same stands for the dynamics of restraint (Straus 2012). The principal aim of this article is therefore to use Côte d'Ivoire to discuss how and why 'islands of peace' emerge during civil war. The crisis in Côte d'Ivoire has not received much scholarly attention. Most of the political analyses have displayed a stereotyped understanding of the dynamics of the conflict as a north-south issue, basically a religious conflict between the Christian South and the Muslim North. There are, of course, more serious analyses on the long-term causes of the civil war (e.g. see Dozon 2011) but there is no clear micro-level analysis and data, especially for the west (for Abidjan, see Banegas 2011). These micro-level dynamics are central to supporting our understanding of the crisis, and providing a link between the political crisis and the logic of violence.

\section{The conceptual puzzle}

Our conceptual puzzle is a difficult one, as there is not an explicit literature on the topic. Given the reverse focus of existing research (the logic of violence rather than of its constraints - the only exception being Straus 2012), let us first assume that in most instances the absence of violence is the opposite of violence. What are the key indicators that could be used to demonstrate how and why communities or individuals would choose to avoid violence during civil war?

The literature on the logic of violence is still in its infancy and most of it focuses on the dynamics of civil war. This literature poses several analytical challenges. First, it is unclear whether and how the dynamics of civil war are distinctive 
from 'interstate war, terrorism, coups, communal violence, political repression, and crime' (Blattman and Miguel 2009: 4). Second, most analysts have assumed that the dynamics of civil war are universally the same. Although a number of patterns and mechanisms stand out in the literature and hypotheses on the roots of civil war and potential causal dynamics are available, a robust body of generalisable research remains out of reach (Blattman and Miguel 2009).

It is important to understand the dynamics of civil war as it will likely determine the logic of violence. Kalyvas and Balcells (2010) have identified three different categories of violence in civil war: 'conventional', 'irregular/guerrilla warfare' and 'symmetric non-conventional'. While it is difficult to characterise a particular conflict in precise (or specific) categories, the civil war in Côte d'Ivoire could be described as a conventional civil war. Kalyvas and Balcells (2010) separate two distinct strands for irregular warfare, namely minor peripheral wars and insurgencies with a radical Islamist outlook. Minor peripheral wars have tended to derive from what Fearon (2004) describes as 'sons of the soil' insurgencies. In a recent article, Fearon and Laitin (2011) reveal that in nearly a third of ethnic civil wars since 1945, the conflict develops between members of a regional ethnic group that considers itself to be the indigenous 'sons of the soil' (autochthons in French) and recent migrants from other parts of the country (allogènes). The migrants are typically members of the dominant ethnic group who migrate in search of land or government jobs, often supported by the state with economic incentives and development schemes. In some ways, one could understand the civil war in Côte d'Ivoire as a combination of two types of war, a conventional civil war opposing a divided army and political class, and a 'sons of soil' insurgency in the west. In fact, the indigenous youth returning from Abidjan and other big cities of Côte d'Ivoire where they were unable to find work, denounced the selling of land to migrants and immigrants by their parents, claiming that the piece of land, their inheritance, was sold without their consent. However, as this article will show, the political dynamics in the west cannot be fully dissociated from the national crisis and the conventional civil war facing both parties.

Conventional civil wars are distinguished from irregular or guerrilla wars because there is comparatively strong military control of populations. Violence against civilians is therefore less concerned with military competition. Direct violence ${ }^{2}$ is generally the result of civilians directly interacting with military actors. Civilians may 'denounce their neighbours, help identify them, or even arrest them (this enhances a group's capacity to assassinate the civilian supporters of its rival)' (Balcells 2010: 4-5). Civilians can also aid in hiding 'potential victims, they can help them flee to other places, or they can give false indications to the groups (this constrains the lethal capacity of groups)' (ibid.). Direct violence against civilians during conventional civil war is 'counterintuitive' because there is little apparent gain for armed groups in killing civilians under their control. Violence that does occur against civilians tends to take place as a result of acquiring additional territory (Balcells 2010: 5) which was clearly the case in Côte d'Ivoire where the 'New Forces' took town after town following the fall of the geostrategic town of Duékoué.

The targeting of civilians is typically the result of 'pre-war political alignments' (Balcells 2010:

6-7). Balcells posits two hypotheses:

1 'The greater the degree of pre-war electoral parity between groups, the higher the level of direct violence perpetrated by the armed group controlling the locality' (Balcells 2009: 9).

2 'The greater the electoral support towards a group during the pre-war period, the greater the likelihood that a locality will be the target of indirect violence by the enemy group' (Balcells 2009: 10).

Direct violence is not linearly associated with the number of supporters of the enemy group (i.e. we do not observe greater leftist violence in places with a greater proportion of rightist supporters) as one could naively assume (i.e. the 'non-domination hypothesis'); instead the relationship is curvilinear. There tends to be greater violence in locales in which there is greater 'parity between political blocs' as there are stronger incentives to shift the balance of power (Balcells 2009: 25). Earlier work by Barron et al. (2004) and Caselli and Coleman (2006) also seems to confirm this hypothesis.

This counterintuitive hypothesis is interesting for our work in that it can both explain the logic 
and restraint of violence in the west. However, this hypothesis is very difficult to check as demographic and ethnic data are either not available or not adequately collected. The different results of the presidential, legislative and municipal elections nonetheless give us a good idea of parity between political parties in the different towns examined. In fact, the case of Duékoué seems to confirm this hypothesis with regards to the logic of violence. But Gagnoa and San Pedro also have a certain parity between political parties and nonetheless have had no violence, at least during the 2010-11 events. ${ }^{3}$ Although this hypothesis provides a key contribution in structuring a spatial analysis, it may become problematic in contexts where the civil war is lengthy and has been going on through different episodes, as in the Ivorian case (2002-12). In fact, data analysis on conflict duration of civil war has shown that

'[A] utonomy-seeking peripheral region insurgencies and "sons-of-the-soil" movements (fought by the local majority against immigrants) tend to last much longer' (Blattman and Miguel 2009: 43), bringing us back to our first point that we also need to understand the factors that might constrain violence.

Understanding the historical trajectories of violence and its restraint is therefore key for a better understanding of the conflict. A number of other explanations could help us to explain the historical dynamics of the conflict. Historical economic analysis, for example, could highlight the impact of the price of cocoa on the causes and dynamics of the conflict. This is certainly an important dimension to keep in mind as Côte d'Ivoire leads the world in the production and export of cocoa beans. One of the interviewees in the town of Guiglo actually mentioned that the market price of cocoa beans had an impact on the cycle of violence. The problem with this explanation is in fact the opposite to Balcells' hypothesis (Balcells 2009); it does not help to explain the variation and constraints of violence in the region throughout which cocoa is produced.

Ashutosh Varshney's (2002) work on India has argued that fragmented social infrastructures, where participation in associational structures and informal networks consolidates identities and interests along, rather than across, religious and ethnic lines, explains variation in violence and peace in otherwise similar areas. He argues that especially in urban areas, day-to-day interactions are sufficient to provide a bridge across ethnic/religious groups and stop conflicts from escalating into communal violence. Communal violence therefore proves less likely in cities where associations can act as bridges across groups (Barron et al. 2004: 9-10). This hypothesis is very interesting for Côte d'Ivoire as it could explain why, in urban areas in the west, violence has diminished in contrast to rural areas. This has inspired other work on social cohesion and levels of trust. Levels of trust and the charisma of key individuals play a further role in shaping the scale of violence. Bhavnani and Backer (2000) argue that low levels of inter-ethnic trust during conflict results in higher levels of violence. This is because communities with weak levels of trust are likely to maintain moderate levels of violence over longer timeframes. This indicates that the trustworthiness among competing groups is just as important as levels of trust within them when perpetrating violence.

Mkandawire (2002: 181) explains rural violence as follows: the African rural setting is generally deeply inimical to liberation war, because peasants enjoy direct control over their own land, and surplus expropriation takes place through the market, rather than through an exploitative landlord class. The African situation, too, has tended to favour 'roving' rather than 'stationary' rebellions, in Olson's terms (Olson 1993); many rebels are merely passing through the countryside, on their way to seek power in towns. Having little in common with the peasantry, and nothing to offer it, they resort to violence as the only way to control it. However incoherent their objectives, and however brutal their methods, rebellions nonetheless reflect a serious urban malaise that needs to be addressed.

A further variable to explain this urban/rural paradox is security. Barron et al. (2004: 29-30) have shown that the presence of communal security arrangements is associated with lower levels of conflict in rural areas. Local governance arrangements are also key for mediating potential conflict. Barron et al. (2004: 31-2) found that the absence of a democratically elected village council is associated with a higher conflict potential. As we will see in our study, local governance institutions and key personalities have played a key role in restraining violence. 


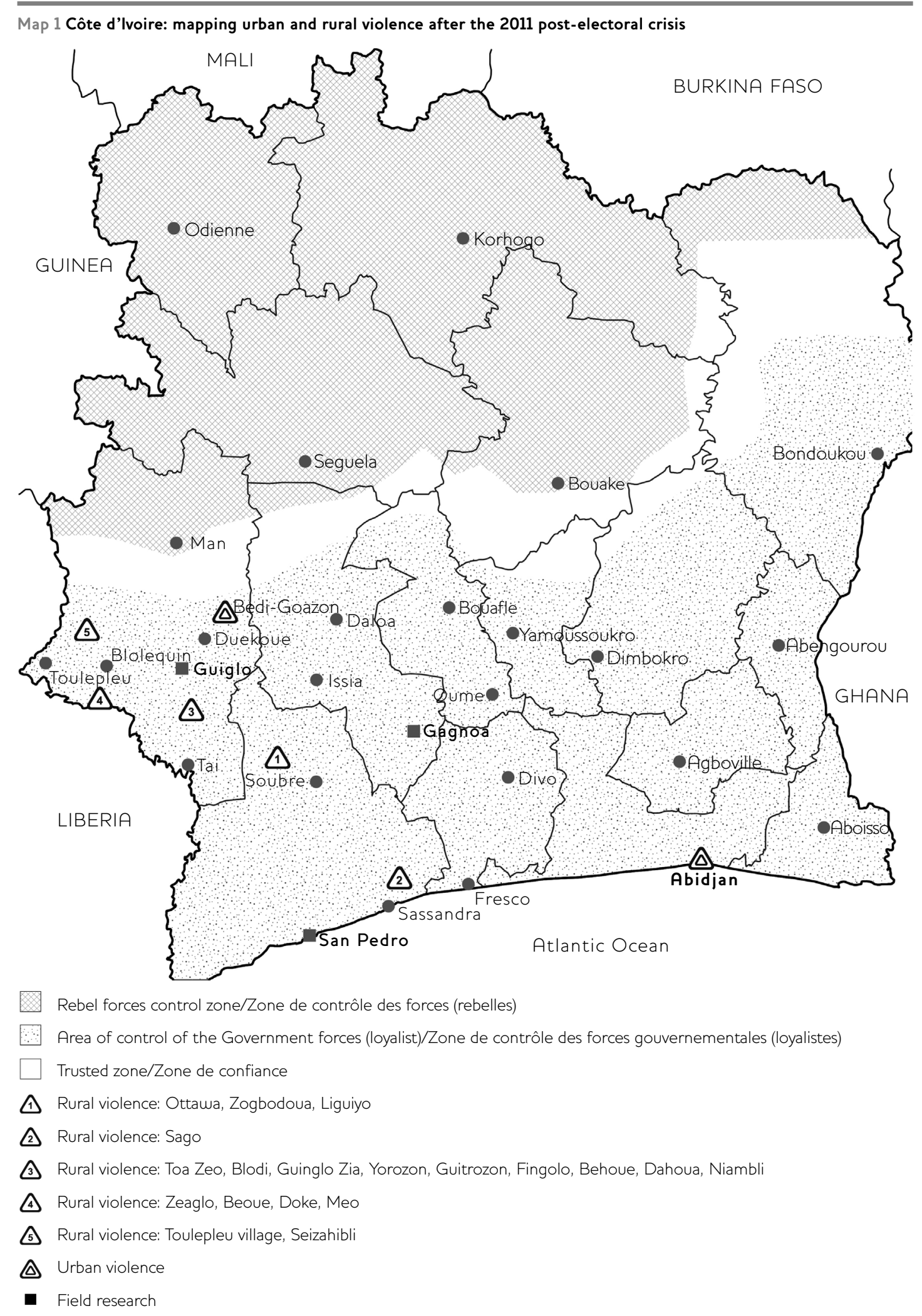

Redrawn from www. parti-ecologique-ivoirien.org/contact/carte-administrative-de-cote-d-ivoire. php. 
Finally, land tenure and mercenary recruitment are two additional elements important in the Ivorian context that are often highlighted as key factors in the dynamics of civil war. While formal land tenure may not necessarily denote security of tenure (World Bank 2003), Bennet (2002) emphasises, for example, that lack of clarity in land rights may be an important factor associated with conflict, while Barron et al. (2004: 8) suggest that the absence of formal property rights for private agricultural land may make this a trigger for violent conflict, especially as land grows more scarce. Macours (2009: i), writing on India, further ' $[\mathrm{s}]$ hows that recruiting by Maoists through abduction of young people was more intensive in districts where inequality between the landed and the landless had previously increased'. This is particularly important as one could observe that the army coming from Bouake was more of a professional army compared to the west where the army was recruiting many mercenaries. This could explain both why violence was more widespread in the west and why recruitment was possible.

If the literature on civil war fails to account for these dynamics, one would have expected scholars in peace studies to have researched these spaces of 'peace in conflict'. However, since the discipline has been influenced and built around concepts of structural violence (Galtung 1969), useful approaches in terms of conflict transformation essentially have been applied in post-conflict settings or peaceful societies (Howell and Willis 1989) and most peace scholars have not engaged with issues related to physical violence.

Overall, the debates have progressed as far as decoupling micro-level conceptual explanations for physical violence from general theories on conflict and war but they have failed to explain the dynamics of 'peace havens' for non-combatants during conflict and war. Existing theories have mostly studied violence through a war and conflict lens by focusing on the perspective of the insurgents or on the government, or even sometimes on the victims. However, by focusing on the perpetrators and victims of violence, the existing theories ignore other political actors and other geographical spaces in civil wars where the level of violence was low or non-existent. The narratives and theoretical explanations that emerge from the perspective of insurgents, government and victims may overstate the lack of social cohesion or insecurity.
By looking at the perspective of other political actors in the conflict, one could broaden the debates on violence and civil war from those that strictly look at the causes of variation of violence to those that focus on other important elements such as the strategies used by third-party actors (to avoid using the term neutral) to escape from violence. It appears that there is still a strong bias in the current literature (that can be partly explained by earlier theories on civil war) to focus on a polarised view of society with, to put it simply, one camp opposed to the other. There are two major problems with this view. Firstly, on a political level, the 'third wave of democratisation' has opened the spaces for alternative views and hence the number of political parties has been growing and diversifying throughout the African continent. Although civil war usually implies a dispute between the ruling party and the major opposition party, there are still a number of influential actors that may situate themselves outside of the dispute by not taking a particular side. These actors nonetheless can still play an important role during a conflict. Secondly, on a societal level, there are still a number of individuals and 'groups' that consider that a resort to military confrontation and physical violence is not necessary.

\section{The civil war in Côte d'lvoire and violence in the west}

The civil war started on 19 September 2002. The government of Gbagbo was threatened by a rebellion in the north and the west ${ }^{4}$ and the country became divided into three areas. A reconciliation process under international auspices was started in 2003. Several thousand French and then West African troops intervened under a UN mandate to maintain peace in the country.

Elections were finally organised in November 2010. Gbagbo was designated as the presidential candidate of the ruling Front Populaire Ivoirien (FPI, Ivorian Popular Front), Alassane Ouattara, who was prime minister from 1990-3, was designated as the presidential candidate of the Rassemblement des Républicains (RDR, Rally of the Republicans), and Henri Konan Bédié, who was president of Côte d'Ivoire from 1993-9, ran as the presidential candidate of his party, the Parti Démocratique de la Côte d'Ivoire (PDCI, Democratic Party of Côte d'Ivoire). However, the results become a source of dispute between Gbagbo and Ouattara, leading to a cycle of 


\begin{tabular}{|c|c|c|c|}
\hline Date & Location & Event & Source \\
\hline 3 January & Duékové & $\begin{array}{l}35 \text { civilians killed and more than } 100 \text { wounded, and } 230 \text { houses } \\
\text { burnt down. Reprisal and counter reprisal attacks by both } \\
\text { allogène and Guéré populations following the killing of an } \\
\text { allogène female trader by an autochthon Guéré highwayman }\end{array}$ & $\begin{array}{l}\text { Amnesty } \\
\text { International } 2011\end{array}$ \\
\hline Mid March & Duékové & 100 Dioula (allogènes) murdered by pro-Gbagbo forces & $\begin{array}{l}\text { Minority Rights } \\
\text { Group } \\
\text { International } 2011\end{array}$ \\
\hline 22 March & Bedi-Goazon & $\begin{array}{l}\text { At least } 37 \text { West African immigrants killed by pro-Gbagbo } \\
\text { militias and Liberian mercenaries }\end{array}$ & $\begin{array}{l}\text { Human Rights } \\
\text { Watch 2011a; } \\
\text { 2011b }\end{array}$ \\
\hline 28 March & Blolequin & $\begin{array}{l}\text { More than } 100 \text { men, women and children from northern } \\
\text { Côte d'lvoire and neighbouring West African countries killed } \\
\text { by pro-Gbagbo militias and Liberian mercenaries }\end{array}$ & $\begin{array}{l}\text { Human Rights } \\
\text { Watch 2011b }\end{array}$ \\
\hline 29 March & Duékové & 330 or $800^{*}$ Guéré killed by pro-Ouattara forces & Le Monde 2011 \\
\hline
\end{tabular}

* 330 or 800 respectively according to UN or ICRC. Source Author's own.

violence and armed confrontations between the insurgents and the army. According to our interview with the US ambassador in Côte d'Ivoire, Ouattara decided on the military option when seven women were assassinated in Abobo and he concluded that political negotiation had failed.

One can distinguish two major dynamics of violence: an urban repressive violence that targeted Muslim Ivorians of northern provenance and West African nationals; and a rural violence, primarily between 'autochtones' and 'allogènes' (Straus 2011). Most of the urban violence was in Abidjan and Duékoué and the rural violence occurred in the western part of the country, in the rural areas around Blolequin, Duékoué, Guiglo, and Toulepleu (see Map 1).

We have much more knowledge about urban violence than rural violence, as the dynamics of rural violence have been less well documented. As pointed out by Straus (2011), many lingering questions remain about the violence in the west, including why certain rural towns but not others were flashpoints, who precisely were the perpetrators, and how extensive was the violence.

Most of the reported violence has only focused on urban casualties. Table 1 summarises the perceived major sites of violence in the west against civilians according to international organisations (IOs) and international nongovernmental organisations (INGOs). The number of victims in Duékoué has been a major point of debate. While the International Committee of the Red Cross (ICRC) considers that more than 800 civilians were killed on 29 March 2011 (ICRC 2011), the United Nations Mission in Côte d'Ivoire (ONUCI) contests this number and talks about 330 victims (Le Monde 2011). ${ }^{5}$ However, during our fieldwork, we found that rural violence had been very widespread.

The current death toll in the west is estimated at more than 500 deaths. The data above are not exhaustive. In fact, during our fieldwork, it was reported to us that there had also been violence against civilians in the town of Issia. One could distinguish two different phases in this dynamic of violence in the west - the first one is a dynamic of retaliation and reprisal from January to March (a spiral pattern of reprisal killing, sometimes on a large scale, in which civilians of one group are collectively punished for the violence of their co-ethnics) and a second phase of pacification and domination by the Forces Républicaines de Côte d'Ivoire (FRCI) from April onwards (see Straus 2011). The situation is still unstable; an administrative officer for the Moyen Cavally region reported to the International Crisis Group (ICG) in May 2011 that the security situation is likely to worsen, 
with fears that the conflict is being transformed into an inter-ethnic confrontation rather than economic one (i.e. land) (ICG 2011).

While the political climate is one of fear, and the data in Table 1 may reveal a cycle of urban violence in the post-electoral crisis, violence against civilians was mainly concentrated in Duékoué, Bedi-Goazon and Blolequin. All the other major towns had no signs of violence (we focused on Gagnoa, Guiglo and San Pedro, but this is also true of Daloa, Divo, Fresco, Oumé, Sassandra, Soubré and Tai). On the other hand, rural violence was widespread in the villages of Soubré (Ottawa, Zogbodoua, Liguiyo), Sassandra (Sago mainly), Duékoué (Toa Zeo, Blodi, Guinglo Zia, Yorozon, Guitrozon, Fingolo, Behoue, Dahoua, Niambli), Blolequin (Zeaglo, Beoue, Doke, Meo) and Toulepleu (Toulepleu village, Seizahibli).

\section{The causes of the conflict in the west}

While the civil war in Côte d'Ivoire has been described as a north-south conflict, the epicentre of the conflict and violence was the western region (Région des 18 Montagnes, Région du Haut-Sassandra and Région du Bas-Sassandra, see Map 1). Of course, the largest city, Abidjan, suffered from military and civilian casualties, especially during the post-electoral crisis (2011-12). However, the west has been the battlefield since 2002 (Gaulme 2003) and the region in fact shows that the underlying structural causes of the conflict go beyond the concept of Ivoirité and the leadership battle between Laurent Gbagbo, Henri Konan Bédié and Alassane Ouattara. These underlying causes include the impact of former president Houphouët-Boigny's (as well as colonial) policies in the region, the repression of politicians of ethnic Bété origins, the politics of modernisation and the management of the land and agricultural policy (see Dozon 2011).

Modernisation policies, in terms of agricultural reform under the government of HouphouëtBoigny, propelled Côte d'Ivoire to become the world's major producer of cocoa beans. The western region has been central to the production of cocoa since 1987. However, this was not without consequences. The expropriation of land to accommodate the port of San Pedro, as well as those displaced to the cocoa region as a result of the Koussou dam, is still part of the collective memory of autochthons. This is not to say that the region as a whole has not benefited from this migration, but it was allowed to develop in an unplanned way. No rules or regulations were established, especially after Houphouët-Boigny's famous slogan, 'the land belongs to those who put it to good use'. Land disputes became inevitable.

The crisis took on a political dimension following the economic crisis that hit Côte d'Ivoire in the early 1980s and the advent of multipartism in the early 1990s. The rise of multipartism, which led to the resurgence of ethno-linguistic and regional political discourses, reanimated problems of the past in the region. In the forest regions, the political party of President Houphouët-Boigny, the PDCI, was perceived as the one that had legitimised the presence of 'foreigners'. Some citizens from the western region felt that the political authority was organising migration without involving the traditional authorities, thereby guaranteeing an unstable relationship between the landowners and the migrants. Whether this is the case or not, the problem lay in the fact that the migration process did not abide by any legal framework. Furthermore, the traditional chiefs had lost their legitimacy and authority as they had been politicised since the advent of multipartism, and could not play their potential role as alternative mediators.

This legal vacuum, as well as the dualism between political and traditional authority, created the basis for the land crisis that started when young students native to this region returned to their homes. Confronted with unemployment in Abidjan and other major cities, the youth returned to the west to discover that their families' land had been leased or sold, creating a number of tensions between the autochthones and the migrants. The temptation by this group to regain control of what they saw as their land created a number of conflicts with the migrants.

This crisis was further exacerbated by its political instrumentalisation with the concept of Ivoirité under the presidency of Henry Konan Bédié, which treated the migrants (even those from the north of the country) as not being genuinely Ivorian (Chauveau 2000). Indeed, the new Land Law was produced in an ethno-nationalist context, allowing some dubious interpretations by various local politicians. This new law in fact 
Figure 1 Price of cocoa beans per tonne, 2002-12

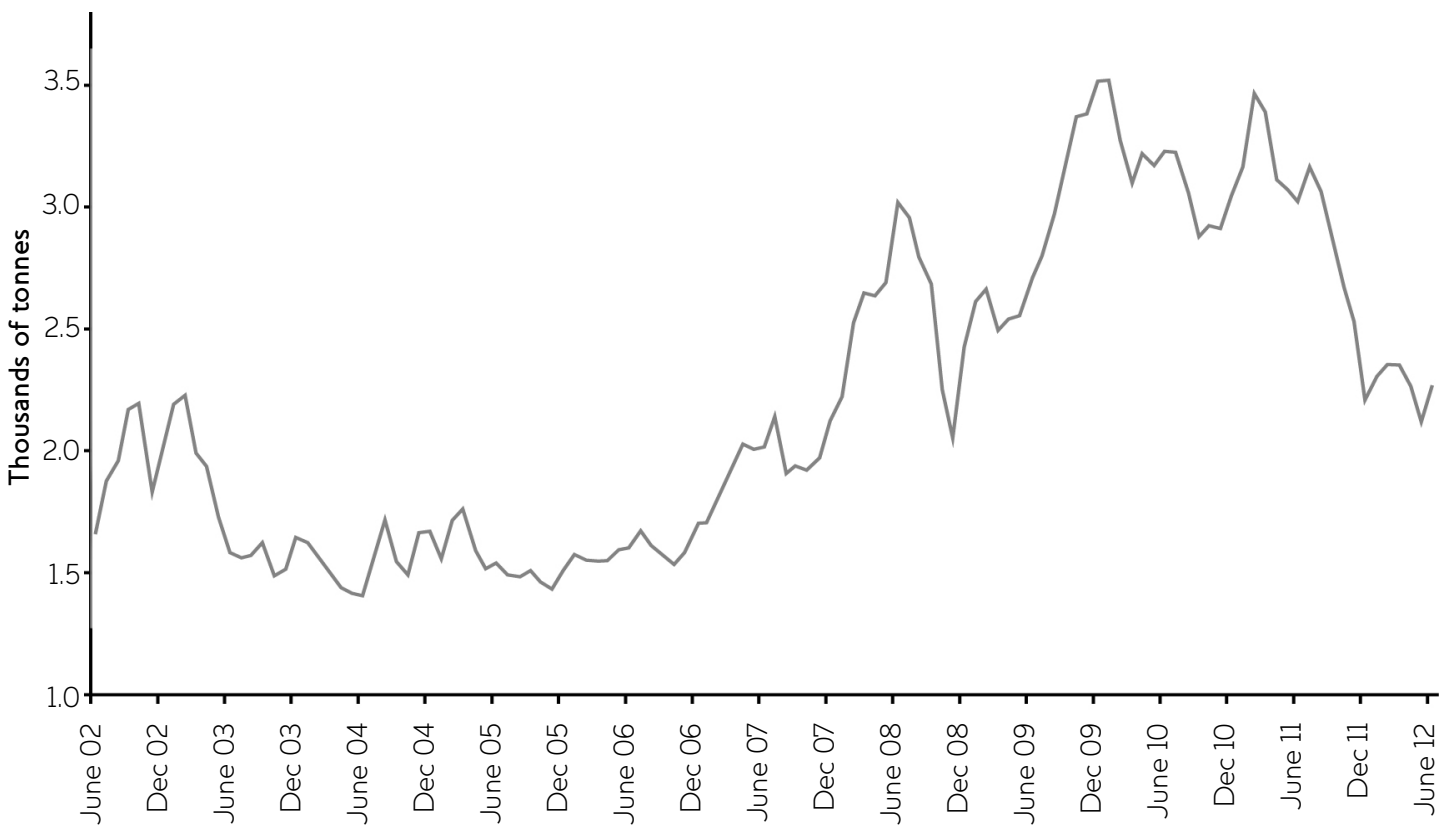

Source www.data.worldbank.org.

brought back to the forefront the tensions that existed between natives and migrants, not only between Ivorians and migrants from neighbouring countries but also migrants from other regions of Côte d'Ivoire. Social cohesion is not only affected by these tensions between migrants and landowners, but also by the tensions between the disillusioned unemployed educated youth and the elders and migrants that had developed a special relationship. There is a sense of betrayal from the viewpoint of the youth who consider that their parents have leased the family land at a time when they needed it the most. Some youths have therefore started contesting these arrangements and have started leasing the land to other migrants, creating complex and explosive situations within families and between migrants.

In 2002, national politics became further confused with the divisions in the region. Many people from the Yacouba region considered Laurent Gbagbo to be behind the assassination in 2002 of former General Guéï, which had important implications for the region as he was a Yacouba from the western Région des 18 Montagnes. This created a division between the Guérés and the Yacouba, very similar to the one observed in Liberia. Obviously the civil war in Liberia reinforced and nurtured these divisions. Political parties and militias at the local level, and ideological and political division at the national level, created a new boundary between the north-west and the south-west. The creation of two new political parties, the Mouvement Patriotique du Grand Ouest (MPIGO) and the Mouvement pour la Justice et la Paix (MJP), is an illustration of this new divide. As a counter-weight, the pastor Gammi created in 2005 the Mouvement de Libération de l'Ouest de la Côte d'Ivoire (MILOCI). This division is new in the Ivorian political landscape and continues to exist up to the present day with the creation of the Union pour la Démocratie et la Paix en Côte d'Ivoire (UDPCI), that now represents the Yacouba group, and the recent election of Mabri Touakeusse as the president of the regional council of Danané, and as a member of parliament.

Finally, the increase in the price of cocoa since 2002 (see Figure 1) has also accentuated the crisis with the expulsion of many Burkinabé in the Région des 18 Montagnes. Producing cocoa and hévéa (rubber) became an attractive business and landowners wanted to benefit from it. Although migrants were expelled from their lands, a narrative commonly heard was that the flow of migration in the region did not stop but actually increased because of terrible droughts 
Table 2 Cycle of violence in Gagnoa, 1995-2010

October 1995 (after the presidential elections)

17 civilians killed following violence between the Bété and the Baoulé and many displaced

26 October 2000 (after the presidential elections)

2 civilians killed and 5 injured, involving combat between militants from the FPI and RDR

November 2003

Hundreds of migrants flee from villages neighbouring

Gagnoa, leading to 8 civilians killed and 11 injured

7-9 November 2004

Violent intercommunal outbreaks leading to 7-15 civilians killed and 29-59 injured

11 August 2005

2 UN military observers attacked by Young Patriots

18 February 2010 (following the dissolution of the

5 civilians killed and 11 injured following a political national unity government) demonstration organised by the opposition parties

in other Western African countries and new illegal plots being developed in the sacred forests.

One can distinguish six major issues in the southwest (Gagnoa, Soubré) and the west (Man, Guiglo):

1 The frustration of the Bété population within the Ivorian nation (Dozon 2011);

2 The land tenure issue in the context of an urban economic crisis which has created interethnic and inter-generational disputes and political instability;

3 The declining legitimacy and authority of traditional chiefs;

4 The desire for revenge among the Yacouba population following the assassination of General Guéï;

5 The proximity with Liberia and the impact of civil war on the region;

6 The price of cocoa.

\section{Gagnoa, Guiglo and San Pedro}

We decided to focus our study of the factors constraining violence during the civil war on three major towns in the west, namely Gagnoa, Guiglo and San Pedro, for the following reasons:

The town of Gagnoa is seen as the capital city for the Bété ethnic group of the former president Laurent Gbagbo. It is a very important town in the political history of Côte d'Ivoire as Kragbé Gnangbé, who had created an opposition political party against Houphouët-Boigny in the $1970 \mathrm{~s}$, is also from this region. It essentially symbolises the major political opposition to Houphouët-Boigny's rule from the 1970s to the 1990s. In this political bastion, one therefore could have expected a strong resistance against the New Forces by the population and militias in order to defend the president, especially since every presidential election since 1995 was followed by the killing of civilians (see Table 2).

The town of Guiglo is just 15 miles away from the town of Duékoué. While the towns of Duékoué, Toulepleu, and Blolequin (see Map 1), as well as the rural areas surrounding these towns, have suffered major civilian massacres, Guiglo has not been affected by a high level of violence against civilians. This provides a very interesting case for our research in that the town had a strong militia governed by Mao Glofiehi and the town was also under the rule of a military prefect. Liberian mercenaries, under the leadership of one socalled 'Bob Marley', were also present.

The town of San Pedro is the most important town in economic terms in the west, as it constitutes the biggest port for cocoa export in the world. The wealthy Lebanese community was very close to Gbagbo, and Young Patriots (les Jeunes Patriotes, a youth militia movement) were also very present, including the nephew of Blé Goudé (Goudé was the leader of the Young Patriots movement).

In order to understand the dynamics of restraint in Côte d'Ivoire, we conducted 40 semi-structured interviews in Abidjan and in the three towns examined. In Abidjan, we interviewed journalists, university researchers and international civil servants at ONUCI. In the three towns in the west, we conducted interviews with Young Patriots, the military, the business community, traditional leaders, and representatives of women's NGOs and the religious community. 


\section{The dynamics of restraint}

It is important that micro-level histories do not ignore the national environment's role in shaping and containing violence. The following factors are important for understanding why the conflict in Côte d'Ivoire, which had the potential to turn into genocide, did not.

The first key factor is the role of the army in the crisis. In most of the towns we visited, there were no direct confrontations between the New Forces and the army that was under the orders of Gbagbo. In fact, since 2002, there has been a crisis of confidence between the former president, Laurent Gbagbo and the army. While General Philippe Mangou was the Chief of Staff of the army, he had no real control over the military's strategic decisions. Vagba Faussigno (Commander of the Navy under Gbagbo), Guiai Bi Poin (Commander of the Centre for Security Operations - CECOS - under Gbagbo), and General Dogbo Ble Denis (Commander of the Republican Guard under Gbagbo) were the key individuals in the army headquarters. It is unclear how loyal the other sections of the army were besides these three regiments. This largely reveals the underlying structural tensions within the army in Côte d'Ivoire. Indeed, since Houphouët-Boigny, there have been many attempted coups d'etat which resulted in purges of the army. As a result, it has been difficult to build a republican army. The army, up to the present day, is a clan-based army.

This lack of confidence led to the creation of parallel militias and mercenaries and the young militant movement, the Young Patriots. The army was either neutral or was slowly taking sides with Alassane Ouattara. Many interviewees talked about a lost war. In fact, there were many in the army that changed sides after the 2010 presidential elections. It was reported during our field trip that the military commander in charge of the second battalion of Daloa changed sides during the war. This was the most important military installation in the west besides Duékoué. In fact, it has been estimated that 63 per cent of security forces (including the police and gendarmerie) had voted in favour of Alassane Ouattara (Zion 2011).

The second key factor is the changing nature of the Young Patriots movement. One could argue that the movement transformed itself from an ideological, political, military force to an organisation of corrupted people; demobilised militiamen engaged in organised crime and gangster activity. In San Pedro, for example, it was reported that different sorts of illegal taxes (road, consumer and property taxes) were collected by the movement. An interviewee in Gagnoa, a local leader of the Young Patriots, told us that this can be explained by the fact that the most radical elements had left to be enrolled in the national army (3,000 in 2003 and 3,000 in 2009).

Thirdly, the New Forces, and especially the Dozos, were feared, at least in the western region, for their mystic powers. Similar to Sierra Leone, these groups were believed to have magical powers to become invisible soldiers. In addition, Dozos have the reputation of killing any adversary they have and of being invincible. After the first battle in Duékoué, one should not underestimate the impact of fear and rumours on the logic of the restraint of violence.

Finally, one should not forget that the government of national unity in 2005 created a new dynamic in the conflict, and the different sides were not as polarised as it may first seem. In fact, during 2005-10, there were no major violent events in the towns in which we conducted our fieldwork. This coalition government certainly had an effect on political alignment and stability in society, although the underlying tensions were still present. In fact, in February 2010, as soon as the government and the independent electoral commission were dissolved, violent incidents occurred in the town of Gagnoa resulting in five deaths and 11 injured. Nonetheless, this period was marked by ambiguity in terms of political alignment. For example, it is unclear to whom the former prime minister and now president of the National Assembly, Guillaume Soro, was aligned. Rumours after the election were circulated that 100 per cent of the votes in his home village were for Laurent Gbagbo. Another interesting fact in this messy political dynamic was that Mao Glofiehi, the principal leader of the Young Patriots in the Guiglo region, revealed after being arrested that he had met Soro after a failed assassination attempt on the former prime minister.

At the local level, we found four major factors leading to restraint. Probably the most important, 
and to a certain extent surprising for external observers of the region, is the level of motivation. We argued above that the Young Patriot movement changed during 2002-12. At the local level in Gagnoa and San Pedro, the Young Patriots interviewed (those in Guiglo had essentially fled) considered that the local politicians had betrayed them. On the one hand, during the post-electoral crisis, arms were apparently not delivered to the Young Patriots, especially in Gagnoa. In fact, it was reported that Bertin Kadet Gahie, former Minister of Defence under Laurent Gbagbo, was travelling to Gagnoa to provide arms when he had an accident. In addition, some of the local authorities who had arms did not give them to the Young Patriots. They also shared with us that all the $\mathrm{DDR}^{6}$ promises in terms of training and indemnisation were never realised. It is difficult to say whether this low level of motivation would have been a deterrent if they had had the opportunity to bear arms during the crisis. (In Rwanda and Sierra Leone violence was perpetrated with quite primitive weapons). However, an important incident in Gagnoa may indeed confirm that the trust in local politicians and the desire to fight for their president was slipping away. In Gagnoa, there was an explosive situation as the security forces had deserted their barracks and the youth from both political wings had stolen all the arms. What happened was that robbery in the major shop of the town became more attractive for both youth groups and acted as a dynamic of restraint. The situation could have easily degenerated but both groups were together in the shop and all became young individuals interested in immediate material gain rather than political confrontation. There was a low level of mobilisation from the population too, especially in Gagnoa. This is all the more surprising as this is the home town of Laurent Gbagbo. The Bété population did not feel that they had fully benefited from any presidential favour. Untarmacked roads in the town of Gagnoa were often given as an example. In fact the major road axes between Gagnoa-Oumé and Gagnoa-Soubré were not in good shape. Overall, the Bété region has not received many benefits in terms of economic and social development programmes or infrastructural development (apart from the Chinese-funded new hospital in Gagnoa).

The second major factor is that unlike many civil wars in the region, state institutions and local governance remains strong and well respected.
In our interviews, we noticed that in the three municipalities, the role of the governors, subgovernors and mayors were vital. In the long term, they have derived their authority from mediating land disputes. This was especially the case with Mr Gauze Ignace Desire, the current sub-governor of Gagnoa. There was one major incident in the town of Gagnoa during the postelectoral crisis. A young Baoulé peasant was burnt by the Young Patriots. The sub-governor intervened straight away and managed to find a negotiated solution between the different communities. In Guiglo, Yahi Octave from the departmental council and Ahoua Touré from Duékoué have played an active role in mediating potential conflict. Reconciliation efforts are made through: the inter-ethnic alliances and joking kinships whose main function is to defuse conflict situations between allied communities; the purification of the earth and the sacrifices initiated by the masks society; and the actions of civil society. These various initiatives have so far helped to consolidate social cohesion. Obviously there are limits to these conflict resolution techniques, as these seemed to have worked in Guiglo but not in Duékoué.

Not only state and political authorities were active but also religious figures. In San Pedro, one of the imams realised how explosive the situation could become as most of the youth were armed following the departure of the security forces. He created his own disarmament programme by asking all the youngsters to deliver their arms to his house. Some enlightened individuals, including some military commanders from the New Forces, also played a key role in restraining the dynamics of violence. Many interviewees in Guiglo mentioned the name of the Commander Moses and the Lieutenant Touré.

The last major factor in these three towns was social cohesion. While conflict between different communities clearly exists, the threat of external actors creates a sense of solidarity within these towns. The most revealing example was in the town of Guiglo where Liberian mercenaries were expelled from town by all the different communities after they started attacking the migrant community. There are several factors that could explain this social cohesion. The first one is that inter-community marriages are quite widespread and while some neighbourhoods were labelled with a particular community 
(e.g. Dioulabougou in Gagnoa), individuals live across the different spaces irrespective of their neighbourhood denotation. Many Young Patriots in Gagnoa were living in Dioulabougou, which may be surprising. Of course, extensive inter-marriage between Hutu and Tutsi did not stop the genocide in Rwanda. Inter-marriage cannot be a restraining factor on its own. The second factor reinforcing social cohesion is that a number of conflict resolution programmes like the GIZ Programme on Peace and Development clearly enabled some of the youth to access alternative livelihoods and reinforced social cohesion. Besides GIZ, CARE International was running a peace programme. Peace committees were set up in villages (between Duékoué and Bangolo). These peace committees were in charge of preventing further violence by solving any issue coming up in the villages. Some of the peace committees are still functioning today. The World Food Programme (WFP) has implemented a 'cash for work' peace dividend programme aimed at supporting people who work either on their farms or contribute to implementing a project of common interest. In the west, Search for Common Ground (SFCG) has broadcast radio programmes promoting social cohesion. By implementing this programme, SFCG has financially supported local radios. Although international organisations have been active in the west, it is unfortunate that except for CARE International, these programmes have been less active in the villages. In addition, a big failure of these programmes was that they could not address the land tenure issue.

\section{Conclusion}

This article has focused on a surprisingly neglected topic as strategies to restrain violence can inform policymakers on conflict resolution mechanisms. Whether it is due to a lack of material on the topic or because it is inextricably linked to the logic of violence and the political dynamics of the civil war, it has been difficult to concentrate our analysis exclusively on the dynamics of restraint in Côte d'Ivoire. In fact, concentrating on individuals and communities would have bypassed one of the major reasons for the dynamic of restraint. In line with Straus (2012), the national environment, and in particular the institutions of the army and militias, proved to be a decisive factor in this dynamic of restraint. The few cases of urban violence are properly explained by local factors and isolated from the rest of the country.
Otherwise there would have been domino effects across the major urban areas in the west. The recent events in July $2012^{7}$ in Duékoué show a particular political history and tragedy that has been going on in this town for the last ten years around revenge and retaliation.

The second important aspect relates to different dynamics of violence and restraint in rural and urban areas. In urban areas, local governance institutions and important personalities have proved to be key figures in the constraint of violence. This was not the case in rural areas where the governor and sub-governor had no physical presence and where the traditional chiefs had lost their authority and legitimacy. This reveals the specificity of the civil war in Côte d'Ivoire which is unusual in that it took place in a country with strong state institutions. While state local institutions were legitimate and strong enough to contain violence in urban areas, the declining authority of chiefs in rural areas meant that no mediator existed in the rural spaces to contain violence.

Researching the reasons for restraints on violence also led us to ask questions about the different outcomes that could have happened in western Côte d'Ivoire. If there had been no rebellion in northern Côte d'Ivoire and if General Guéï had not been assassinated, would western Côte d'Ivoire be different from how it is today? Our analysis has highlighted that the problems of land ownership must be a central concern for the stabilisation of the western region. Land tenure issues result from governance failures dating from the period of Félix Houphouët-Boigny. The strategic importance of this region (the main area of cocoa production) requires the resolution of problems of cohabitation. The search for peace and national reconciliation must begin in the west, especially as the stigma and the politicisation of the Ivorian conflict as a northsouth conflict cannot mask the major problem of the Ivorian crisis: the issue of land ownership. It is unfortunate that peace programmes in the west did not sufficiently address this issue. Most programmes, except for CARE International, were focusing on promoting social cohesion and mainly in towns. The new government has shown some positive signs of will to solve the issue of land tenure but it will be a difficult political game given the current coalition with the PDCI, 
as well as the positive relationship with President Blaise Compaoré of Burkina Faso. Furthermore, the new security situation in the west following the crisis and the presence of Dozos, or newly

\section{Notes}

* The authors would like to thank David Leonard and Scott Straus for their very valuable comments, Matthew Benson and Mathilde Gingembre for their work as research assistants, and Shona McCulloch and Freida Ibiduni M'Cormack for their editorial support.

1 The Agreement was signed in France on 24 January 2003 by the main political parties and rebel groups to put an end to the political crisis and civil unrest that had engulfed Côte d'Ivoire since 19 September 2002. President Gbagbo was to retain power and opponents were invited into a government of reconciliation and obtained the ministries for Defence and the Interior. A peace line was established with the presence of the Economic Community of West African States (ECOWAS) and French soldiers.

2 Indirect violence could result from heavy weaponry such as tanks and fighter planes and therefore does not demand direct contact between combatants and non-combatants.

3 During presidential elections in 2000, Duékoué, Gagnoa and San Pedro voted in the

\section{References}

Amnesty International (2011) Côte d'Ivoire Mission Report, AFR 31/001/2011, 22

Balcells, L. (2010) 'Rivalry and Revenge: Violence against Civilians in Conventional Civil Wars', International Studies Quarterly 54: 291-313

Balcells, L. (2009) 'Politics by Two Means: Direct and Indirect Violence in Civil War', prepared for the Annual Meeting of the Political Science Association Meeting, Toronto, September

Banegas, R. (2011) 'Briefing: Post-Election Crisis in Côte d'Ivoire: The Gbonhi War', African Affairs 110.440: 457-68

Barron, P.; Kaiser, K. and Pradhan, M. (2004) 'Local Conflict in Indonesia: Measuring Incidence and Identifying Patterns', presented at the Cornell Conference: 75 Years of Development Research, Cornell, May

Bassett, T. (2003) “"Nord Musulman et Sud Chrétien”: les Moules Médiatiques de la Crise Ivoirienne', Afrique Contemporaine 206: 13-27 initiated Dozos, has rendered the land issue more fragile and explosive. The land issue in Côte d'Ivoire, and in the west particularly, is far from being resolved.

majority for Laurent Gbagbo. But whilst the mayor of Duékoué, and the members of parliament elected in Duékoué, Gagnoa and San Pedro are from Gbagbo's political party, the mayors of Gagnoa and San Pedro were elected from the Rassemblement des Républicains (RDR, Rally of the Republicans), the party of Alassane Ouattara.

4 By three rebel movements: the Mouvement Patriotique de la Côte d'Ivoire (MPCI), the Mouvement Patriotique du Grand Ouest (MPIGO) and the Mouvement pour la Justice et la Paix (MJP).

5 www.lemonde.fr/afrique/article/2011/04/02/ des-affrontements-ont-fait-au-moins-800morts-a-duekoue-selon-le-cicr_1502042_ 3212.html\#ens_id=1476585.

6 Disarmament, Demobilisation and Reintegration of ex-combatants.

7 On 20 July 2012 the Internally Displaced Persons camp of Nahibly, where 5,000 indigenous Guéré had been living since March 2010, was completely burnt out by Dozos and northerners, arguing that bandits and proGbagbo militias were living in the camp. Officially 11 people were killed.

Bennet, Chris P.A. (2002) 'Toward Resolution of Conflict between Customary (Adat) Land Rights and State Land Management through Greater Transparency of Land Information', paper presented at a meeting on The Perspective of Customary Land Rights in Approaches to Comprehensively Resolve Land Conflicts, 19-20 June, Ministry of Home Affairs, Jakarta

Bhavnani, R. and Backer, D. (2000) 'Localized Ethnic Conflict and Genocide: Accounting for Differences in Rwanda and Burundi', Journal of Conflict Resolution 44.3: 283-306

Blattman, C. and Miguel, E. (2009) Civil War, Center for International and Development Economics Research, Institute of Business and Economic Research, Working Paper qt90n356hs, Berkeley: University of California Caselli, F. and Coleman, W.J. (2006) On the Theory of Ethnic Conflict, Centre for Economic Performance Discussion Paper 732, London: London School of Economics and Political Science 
Chauveau, J.P. (2000) 'Question Foncière et Construction Nationale en Côte d'Ivoire', Politique Africaine 78: 94-125

Dembélé, O.; le Papa, M. et al. (2002) La Construction Economique et Politique de la Catégorie 'Etranger' en Côte d'Ivoire. Côte d'Ivoire. L'Année Terrible 1999-2000, Paris: Karthala: 123-71

Dozon, J.P. (2011) Les Clefs de la Crise Ivoirienne, Paris: Karthala

Fearon, J.D. (2004) 'Why Do Some Civil Wars Last So Much Longer than Others?', Journal of Peace Research 41.3: 275-301

Fearon, J.D. and Laitin, D.D. (2011), 'Sons of the Soil, Migrants, and Civil War', World Development 39.2: 199-211

Galtung, J. (1969) 'Violence, Peace and Peace Research', Journal of Peace Research 6.3: 167-91

Gaulme, F. (2003) La Côte d'Ivoire et la Dynamique Conflictuelle en Afrique de l'Ouest: une Approche Régionale pour une Action Concertée, Paris: Agence Française de Développement

Howell, S. and Willis, R. (eds) (1989) Societies at Peace: Anthropological Perspectives, New York: Routledge

Human Rights Watch (2011a) Côte D'Ivoire: West African Immigrants Massacred, 31 March, New York: HRW

Human Rights Watch (2011b) Côte d'Ivoire: Ouattara forces Kill, Rape, Civilians During Offensive, 9 April, New York: HRW

ICG (2011) Une Période Critique pour Stabiliser la Côte d'Ivoire, Africa Report 176, Brussels: International Crisis Group

ICRG (2011) Côte d'Ivoire: des Centaines de Civils Tués à Duékoué, 01-04-2011, Communiqué de presse, International Committee of the Red Cross, www.icrc.org/fre/resources/documents/ news-release/2011/cote-d-ivoire-news-2011-0104.htm (accessed 23 August 2012)

Kalyvas, S. (2006) The Logic of Violence in Civil Wars, Cambridge: Cambridge University Press

Kalyvas, S. and Balcells, L. (2010) 'International System and Technologies of Rebellion: How the End of the Cold War Shaped Internal Conflict', American Political Science Review 104.3: 415-429
Le Monde (2011) 'Des Affrontements ont Fait au Moins 800 Morts à Duékoué, Selon le CICR', Le Monde.fr avec AFP et Reuters, 2 April, www.lemonde.fr/afrique/article/201 1/04/02/des -affrontements-ont-fait-au-moins-800-morts-aduekoue-selon-le-cicr_1502042_3212.html \#ens_id=1476585 (accessed 23 August 2012)

Macours, K. (2009) Increasing Inequality and Civil Conflict in Nepal, School of Advanced International Studies Working Paper, Washington DC: Johns Hopkins University

Mkandawire, T. (2002) 'The Terrible Toll of PostColonial "Rebel Movements" in Africa: Towards an Explanation of the Violence Against the Peasantry', Journal of Modern African Studies 40.2: 181-215

Minority Rights Group International (2011) MRG Strongly Condemns Ethnically Motivated Attacks on Civilians in Côte D'Ivoire, Calls On New Administration to Investigate Killings, 11 April, www.unhcr.org/refworld/docid/4dfb653bla.html (accessed 23 August 2012)

Olson, M. (1993) 'Dictatorship, Democracy, and Development', American Political Science Review 87.3: 567-76

Straus, S. (2012) 'Retreating from the Brink: Theorizing Mass Violence and the Dynamics of Restraint', Perspectives on Politics 10: 343-62

Straus, S. (2011) 'Briefing: "It's Sheer Horror Here": Patterns of Violence During the First Four Months of Côte d'Ivoire's Post-Electoral Crisis', African Affairs 110.440: 481-89

Varshney, A. (2002) Ethnic Conflict and Civic Life: Hindus and Muslims in India, New Haven CT: Yale University Press

Wood, E. (2003) Insurgent Collective Action and Civil War in El Salvador, Cambridge: Cambridge University Press

World Bank (2003) Land Policies for Growth and Poverty Reduction 239, Washington DC: World Bank

Zion, D.K. (2011) 'De Quoi des ex-Fds ont-ils Peur?', Le Nouveau Réveil 2778, 30 April 